\title{
HMGB1 Switches Alkylating DNA Damage-Induced Apoptosis to Necrosis
}

\author{
Su Yeon Lee', Eui Kyong Jeong ${ }^{1}$, Hyun Min Jeon', Min Kyung Ju', Cho Hee Kim", \\ Hye Gyeong Park ${ }^{2}$ and Ho Sung Kang *
}

${ }^{1}$ Department of Molecular Biology, College of Natural Sciences, ${ }^{2}$ Nanobiotechnology Center, Pusan National University, Busan 609-735, Korea Received May 12, 2011 /Revised June 22, 2011 /Accepted July 4, 2011

\begin{abstract}
Necrosis is characterized by the cell membrane rupture and release of the cellular contents, including high-mobility group box 1 protein (HMGB1), into the extracellular microenvironment. HMGB1 acts as a transcriptional regulator in nuclei, but exerts a pro-inflammatory and tumor-promoting cytokine activity when released into the extracellular space. Its overexpression is associated with tumor progression and chemoresistance. Thus, HMGB1 acts as a clinically important molecule in tumor biology. In this study, we examined whether HMGB1 affects cell death induced by anti-cancer drugs. Here we show that HMGB1 prevented cisplatin (alkylating agent)-induced apoptosis and switched the cell fate to necrosis in MCF-7, MDA-MB231, and MDA-MB361 cells. Similar apoptosis-to-necrosis switch effects of HMGB1 were observed in cells treated with 4-HC, another alkylating agent. In contrast, HMGB1 did not exert any significant effects on docetaxel (DOC)-induced apoptosis in MCF-7 cells. We also show that cisplatin-induced apoptosis was switched to necrosis in MCF-7 multicellular tumor spheroids (MTS) that were cultured for 8 days and had necrotic cores, but DOC-induced apoptosis was prevented without the apoptosis-to-necrosis switch. Finally, the levels of RAGE, a receptor of HMGB1, were increased with extended culture of MTS. These findings demonstrate that HMGB1 switches alkylating agent-induced apoptosis to necrosis, suggesting that the strategy to prevent necrosis occurring as an undesirable action of alkylating agent-based chemotherapy should be delineated to improve the efficacy of chemotherapy for cancer.
\end{abstract}

Key words : High-mobility group box 1 protein (HMGB1), apoptosis, necrosis, multicellular tumor spheroid

\section{Introduction}

Apoptosis and necrosis are two major cell death types. In contrast to apoptosis, in which cells are progressively fragmented into apoptotic bodies that are removed by professional phagocytic cells, necrosis is characterized by the cell membrane rupture and releases the cellular contents including high-mobility group box 1 protein (HMGB1) into the extracellular microenvironment $[13,14,18,22,32]$. Furthermore, necrotic cells recruit immune inflammatory cells, which exert a tumor promoting activity through inducing angiogenesis, cancer cell proliferation, and invasiveness $[7,25,30]$. Necrosis is commonly found in the core region of solid tumors. Development of necrotic core in cancer patients is correlated with increased tumor size, highgrade disease, and poor prognosis, such as emergence of chemoresistance and metastasis [5,31,32]. Thus, necrosis is regarded as 'a reparative cell death' to promote tumor growth.

\footnotetext{
${ }^{\dagger}$ Present

DNA Identification Center, National Forensic Service, Seoul, Korea *Corresponding author

Tel : +82-51-510-2275, Fax : +82-51-513-9258

E-mail : hspkang@pusan.ac.kr
}

HMGB1, a chromatin associated nuclear protein, acts as a transcriptional regulator in nuclei [29]. HMGB1 could be released with sustained autophagy, late apoptosis and necrosis and acts as one of the damage-associated molecular pattern molecules $[24,27,28]$. HMGB1 binds to the receptor for advanced glycation end products (RAGEs) that is a member of the immunoglobulin gene superfamily, encoded within the major histocompatability complex class III region, as well as Toll-like receptor 4. Activation of RAGE by HMGB1 leads to cellular damage contributing to inflammation, traumatic cell death, diabetic complications, myocardial inflammation, and injury induced by ischemia-reperfusion [15,20]. HMGB1 is implicated in cancer tumor progression through exerting proliferative activity, promoting blood vessel development (angiogenesis), inhibiting apoptosis, conferring insensitivity to chemotherapy, and inducing tumor invasion and metastasis $[9,20,25,28,29]$. Thus, HMGB1 acts as a clinically important molecule in tumor biology; however, its molecular mechanism has been poorly understood.

Anticancer drugs exert tumor-suppressive effects by inducing cell cycle arrest, senescence (a naturally irreversible cell-cycle arrest), mitotic catastrophe, apoptosis, and autophagy depending on the stimulus and cell type; high concen- 
trations of anticancer drugs induce cell cycle arrest, senescence, mitotic catastrophe, apoptosis, and autophagy, whereas low doses of anti-cancer drugs induce epithelial mesenchymal transition (EMT) that is associated with tumor invasion and metastasis as undesirable effects in cancer treatment $[1,3,23]$. In this study, we examined whether HMGB1 affects the cell death induced in MCF-7, MDA-MB231, and MDA-MB361 cells by anti-cancer drugs including cisplatin (a DNA alkylating agent), 4-hydroperoxy-cyclophosphamide (4-HC, an alkylating agent and an activated analogue of cyclophosphamide), and docetaxel (DOC, taxotere, an inhibitor of microtubule remodeling that stabilizes microtubules and prevents tubulin depolymerization). Here we show that HMGB1 prevents alkylating agents (cisplatin and 4-HC)-induced apoptosis and switches the cell fate to necrosis in MCF-7, MDA-MB231 and MDA-MB361 cells, without affecting any significant effects on DOC-induced apoptosis in MCF-7 cells. We also found that cisplatin-induced apoptosis was switched to necrosis in MCF-7 multicellular tumor spheroids (MTS) that were cultured for 8 days and had necrotic core. In addition, we observed that the levels of RAGE were increased with extended culture of MTS. These findings demonstrate that HMGB1 switch chemotherapy-induced apoptosis to necrosis. This implies that the current alkylating agent-based chemotherapy needs to be reconsidered.

\section{Materials and Methods}

\section{Cell culture and HMGB1 treatment}

MCF-7, MDA-MB-231, MDA-MB-361, HepG2, and A549

cells were obtained from American Type Culture Collection, maintained in RPMI-1640 or DMEM supplemented with 10\% (v/v) heat-inactivated fetal bovine serum (HyClone, Logan, UT, USA) and $1 \%$ penicillin-streptomycin (HyClone, Logan, UT, USA) in a $37^{\circ} \mathrm{C}$ humidified incubator with $5 \% \mathrm{CO}_{2}$ as described previously [17]. Recombinant human HMGB1 protein (rhHMGB1) was obtained from HMGBiotech (Milano, Italy), and was treated at concentration of $100-200 \mathrm{ng} / \mathrm{ml}$ for $72 \mathrm{hr}$.

\section{Drug treatment}

Cisplatin and DOC were purchased from Sigma (St. Louis, MO, USA), 4-HC was purchased from Baxter Oncology $\mathrm{GmbH}$. Cisplatin and DOC were dissolved in dimethyl sulfoxide, and 4-HC were dissolved in distilled water. The drugs were then divided into aliquots and stored at $-20^{\circ} \mathrm{C}$ until used. The stocks were freshly diluted in culture medium before any experiment. The chemicals were treated as indicated in the Fig. legend for 24-48 hr.

Multicellular tumor spheroid (MTS) culture and
staining

MCF-7, MDA-MB-231, and MDA-MB-361 cells were seeded at a density of 400 cells in $200 \mathrm{ml}$ medium into $1.2 \%$ agarose-coated 96-well plates. After 3 days of culture, $100 \mathrm{ml}$ of medium was replaced with fresh medium every 2 days. MTSs were harvested and fixed in formalin. After processing into wax blocks, the spheroids were sectioned, and stained with hematoxylin and eosin, stained with $\mathrm{HO} / \mathrm{PI}$.

\section{Immunoblotting}

Protein lysates obtained from 2-D and 3-D culture cells were measured using the Bradford assay (Bio-Rad, Richmond, CA, USA) and equal amounts of protein lysates were separated by sodium dodecyl sulfate-polyacrylamide gel electrophoresis on $12 \%$ gels, and electrotransferred to NC paper and treated with anti-RAGE (Santa Cruz Biotechnology, Santa Cruz, CA, USA) and anti-a-tubulin (Biogenex, San Ramon, CA, USA) antibodies. After incubation with peroxidase-conjugated secondary antibody protein expression was detected using ECL Western Blotting Detection Reagents (Amersham Biosciences, Buckinghamshire, UK).

\section{Hoechst $33342 \quad(\mathrm{HO}) /$ propidium iodide (PI) staining} and immunofluorescence microscopy

Anti-cancer drug-induced cell death mode was determined by Hoechst 33342 (HO)/propidium iodide (PI) double staining as described previously [17]. DNA-binding dyes $\mathrm{HO}$ penetrates the plasma membrane of all cells, whether they are damaged or not, causing a blue fluorescence of their nuclei and PI only penetrates cells with damaged membranes and leads to nuclear fluorescence. Thus, intact blue nuclei, condensed/fragmented blue nuclei, condensed/fragmented pink nuclei, and intact pink nuclei indicate viable, early apoptotic, late apoptotic (secondary necrotic), and necrotic cells, respectively.

\section{Statistical analysis}

All experiments were independently performed at least three times. Data were analyzed by the Student's t-test and $p<0.05$ was considered statistically significant. 
Results

Anti-cancer drug-induced cell death mode

To examine the cytotoxic effects of cisplatin and DOC in 2-dimensional (2-D) culture of MCF-7, MDA-MB231,
MDA-MB361, HepG2, and A549 cells, the cells were treated with different concentrations of these chemotherapeutic drugs and analyzed by $\mathrm{HO}$ and PI double staining to identify apoptosis and necrosis. As shown in Fig. 1, cisplatin exerted the cytotoxic effects on MCF-7 cells in a dose-depend-

A
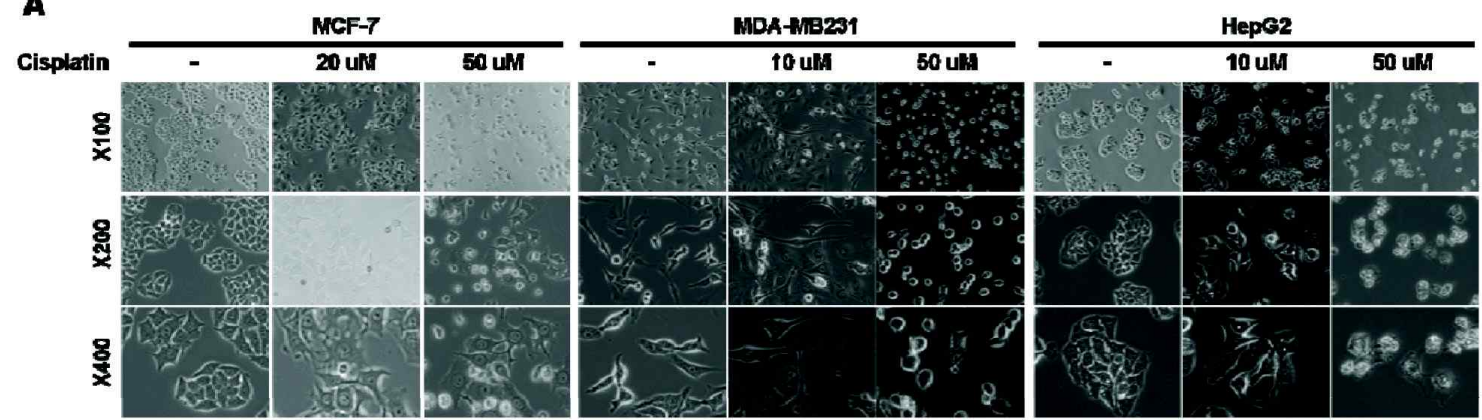

B

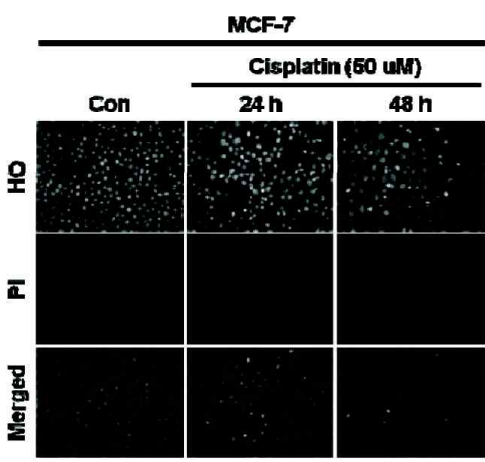

MDA-MB234

HepG2
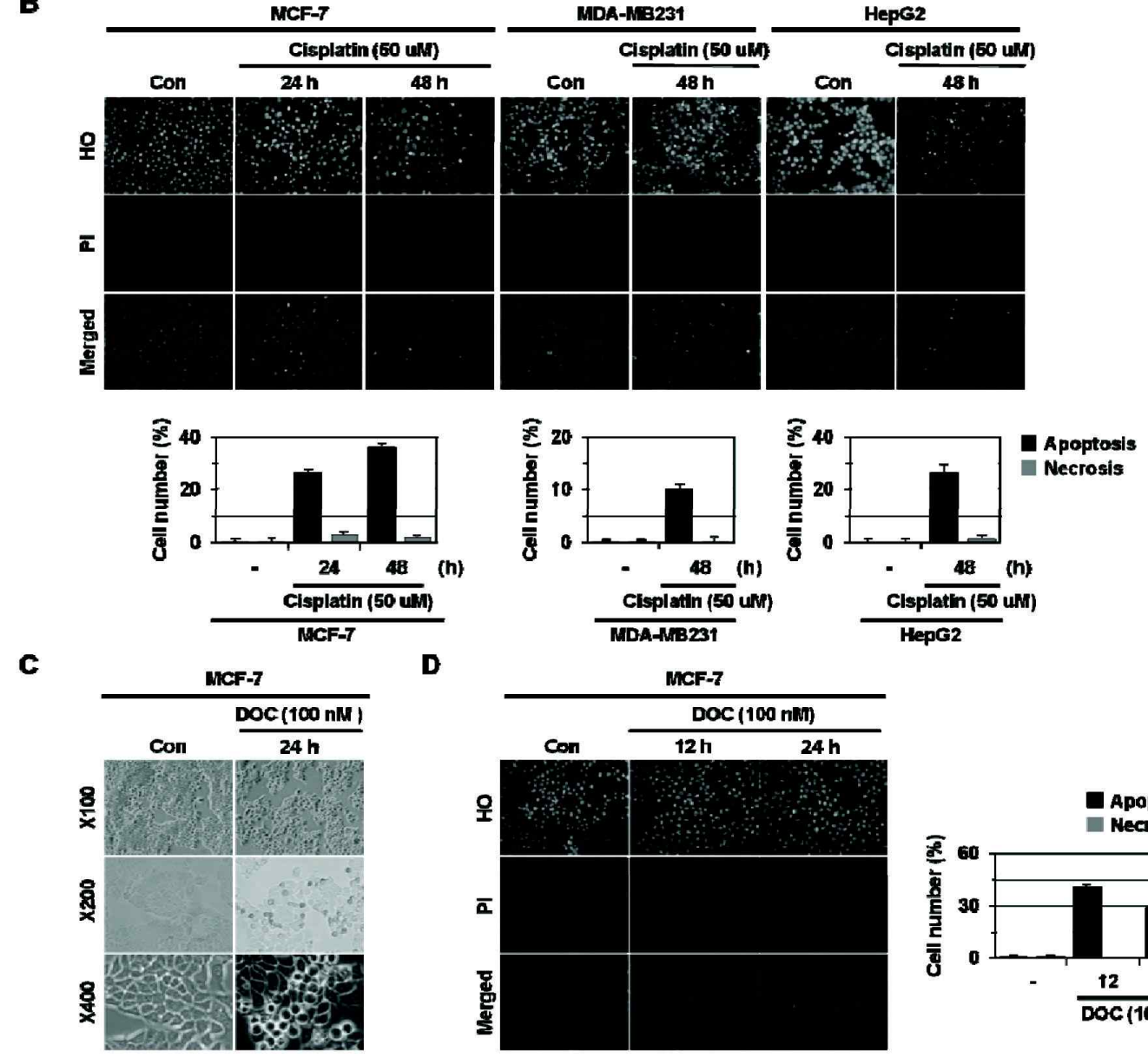

D
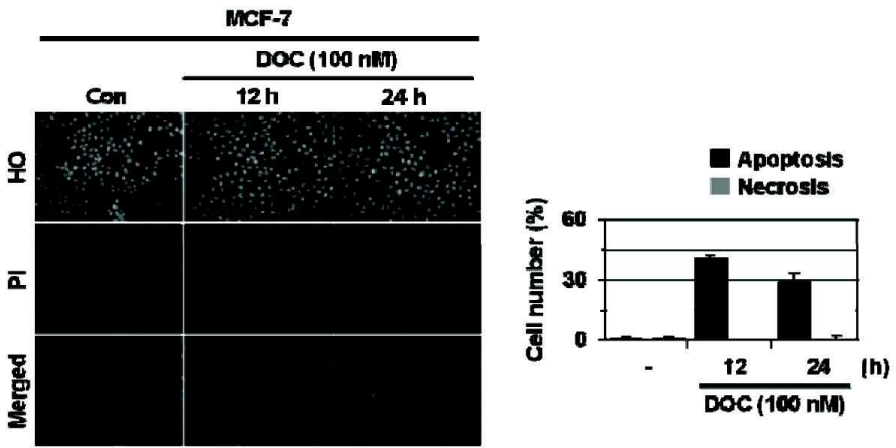

Fig. 1. Cisplatin- and DOC-induced apoptotic cell death in cancer cell lines. (A-B) MCF-7, MDA-MB231, and HepG2 cells were exposed to 10-50 $\mu \mathrm{M}$ cisplatin for 24-48 hr and observed under light microscopy (panel A) and stained with HO and PI and observed by fluorescence microscopy (panel B), and apoptotic and necrotic cells were scored. (C-D) MCF-7 cells were treated with $100 \mathrm{nM} \mathrm{DOC}$ for 12-24 hr, and the morphological feature of cells were observed by light microscopy (C) and then stained with $\mathrm{HO} / \mathrm{PI}$, and observed with fluorescence microscopy (D), and apoptotic and necrotic cells were scored. Results (500-800 cells in each group) are expressed as the means \pm SE from three independent experiments. 
ent manner. MCF-7 cells treated with lower concentrations of cisplatin ( $20 \mu \mathrm{M}$ for $48 \mathrm{hr}$ ) exhibited senescence-like cell morphology, whereas those treated with higher concentrations of cisplatin (50 $\mu \mathrm{M}$ for $48 \mathrm{hr}$ ) showed morphology typical of apoptosis such as chromatin condensation and nuclear fragmentation. Similar low dose-induced cell morphological changes and high dose-induced apoptosis were observed in cisplatin-treated MDA-MB231, HepG2 (Fig. 1A and B), MDA-MB361, and A549 cells (data not shown).

We also examined the cytotoxicity of a microtubule disassembly inhibitor, DOC, against MCF-7 cells. After $48 \mathrm{hr}$ exposure to $100 \mathrm{nM} \mathrm{DOC}$, we observed the characteristic features of apoptotic cell deaths including nuclear chromatin condensation and the appearance of typical apoptotic bodies (Fig. 1C and D). In addition, multinucleated giant cells due to mitotic arrest and EMT-like phenotypes were observed. Similar results were obtained in MDA-MB231 cells that were treated with DOC (data not shown).

\section{Effects of HMGB1 on anti-cancer drug-induced} cell death mode

We examined the impact of HMGB1 on anti-cancer drug-induced cell death. As shown in Fig. 2A, rhHMGB1 caused an alteration in cell morphology to mesenchymal cell-like phenotype. In accordance with this observation, HMGB1 is known to induce invasion and metastasis in vari-
A

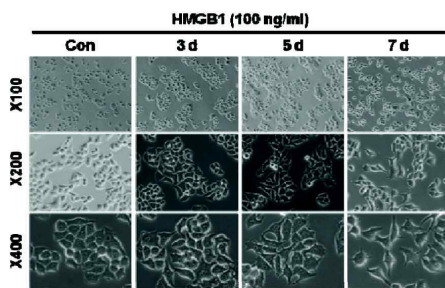

B

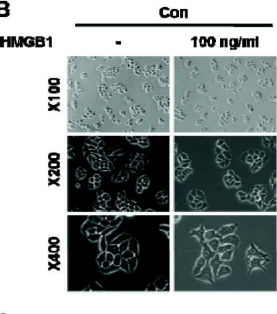

c HMGB1
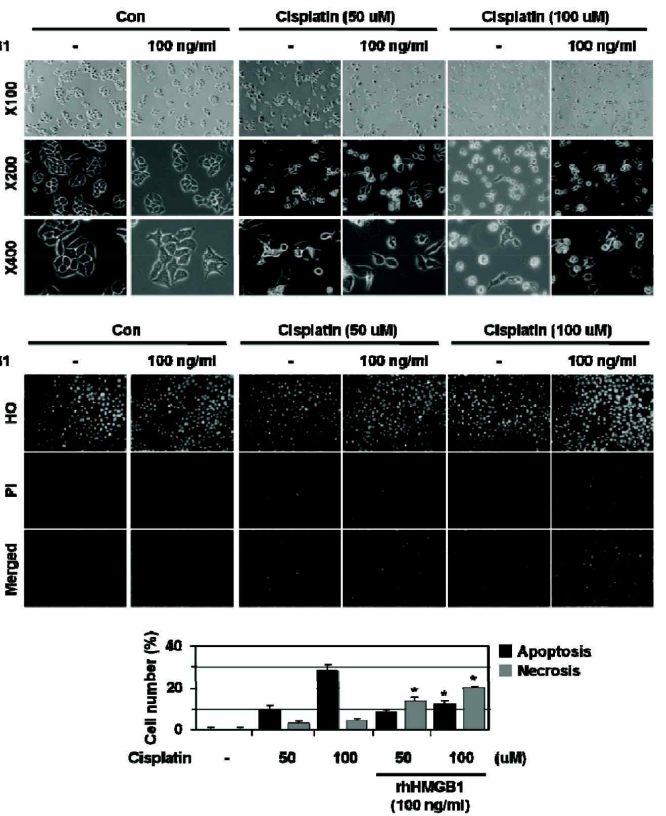

D

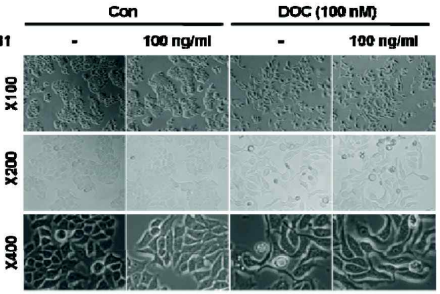

E
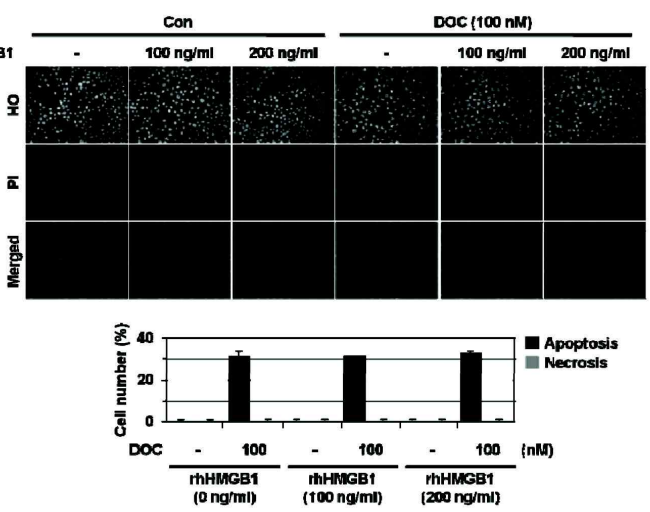

Fig. 2. Effects of HMGB1 on cisplatin- and DOC- induced cell death mode. (A) MCF-7 was exposed to $100 \mathrm{ng} / \mathrm{ml} \mathrm{rhHMGB1}$ for 3-7 days, and the morphological features of cells were observed by light microscopy. (B-C) MCF-7 cells were pre-treated with $100 \mathrm{ng} / \mathrm{ml} \mathrm{rhHMGB1}$ for $72 \mathrm{hr}$ and exposed to $50 \mu \mathrm{M}$ and $100 \mu \mathrm{M}$ cisplatin for $24 \mathrm{hr}$, and the morphological feature of cells were observed by light microscopy (B), and stained with HO/PI, and observed with fluorescence microscopy (C), and apoptotic and necrotic cells were scored. Results (500-800 cells in each group) are expressed as the means \pm SE from three independent experiments. ${ }^{*} p<0.05$ versus cisplatin alone. (D) MCF-7 cells were pre-treated with $100 \mathrm{ng} / \mathrm{ml} \mathrm{rhHMGB1}$ for $72 \mathrm{hr}$ and exposed to $100 \mathrm{nM}$ DOC for $48 \mathrm{hr}$, and the morphological feature of cells were observed by light microscopy. (E) MCF-7 cells were pre-treated with $100 \mathrm{ng} / \mathrm{ml}$ and $200 \mathrm{ng} / \mathrm{ml} \mathrm{rhHMGB1}$ for $72 \mathrm{hr}$ and exposed to $100 \mathrm{nM}$ DOC for $24 \mathrm{hr}$ and stained with $\mathrm{HO} / \mathrm{PI}$, and observed with fluorescence microscopy, and apoptotic and necrotic cells were scored. Results are expressed as mean \pm SE from 500 to 800 cells per treatment group and from three independent experiments. 
ous human malignancies $[19,26]$. To investigate the effects of HMGB1 on drug-induced cell death, MCF-7, MDA-MB231, and MDA-MB361 cells were pre-treated with rhHMGB1, and then exposed to anti-cancer drugs. rhHMGB1 (100-200 ng/ml) appeared to significantly prevent cisplatin-induced apoptosis and switched the cell death mode to necrosis in MCF-7 (Fig. 2B and C), MDA-MB231, and MDA-MB361 cells (data not shown), indicating that rhHMGB1 caused the cell death mode switch from apoptosis to necrosis. In contrast, rhHMGB1 did not exert any sig- nificant effects on DOC (100 $\mathrm{nM})$-induced apoptotic cell death in MCF-7 cells (Fig. 2D and E).

Anti-cancer drug-induced cell death mode in 3D multicellular tumor spheroid

Three-dimensional (3-D) multicellular tumor spheroid has been widely used as in vitro tumor model for chemoresistance study because it has closely similar growth characteristics of in vivo tumor and resembles avascular regions of large solid tumors $[2,4,10]$. MTS exhibits a proliferation

A

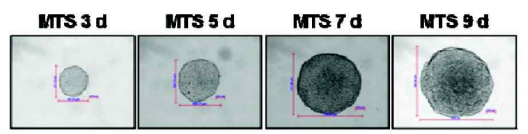

B
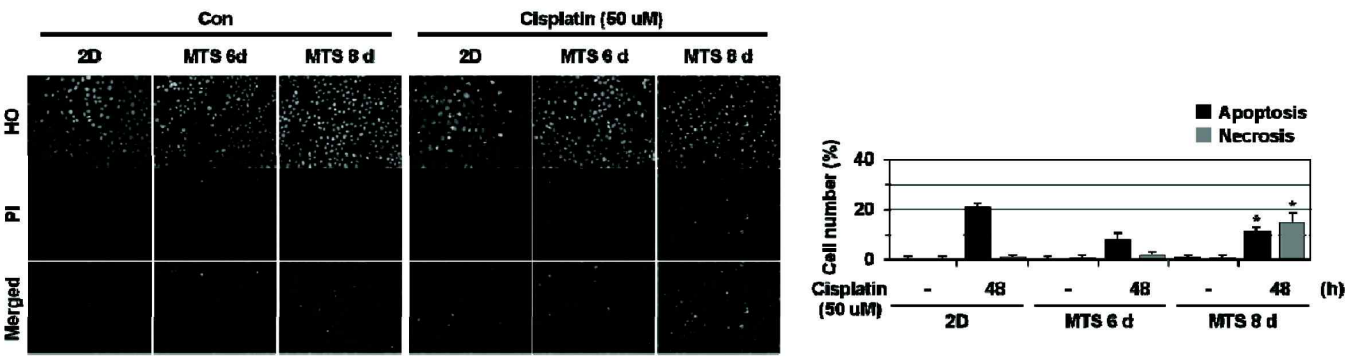

c
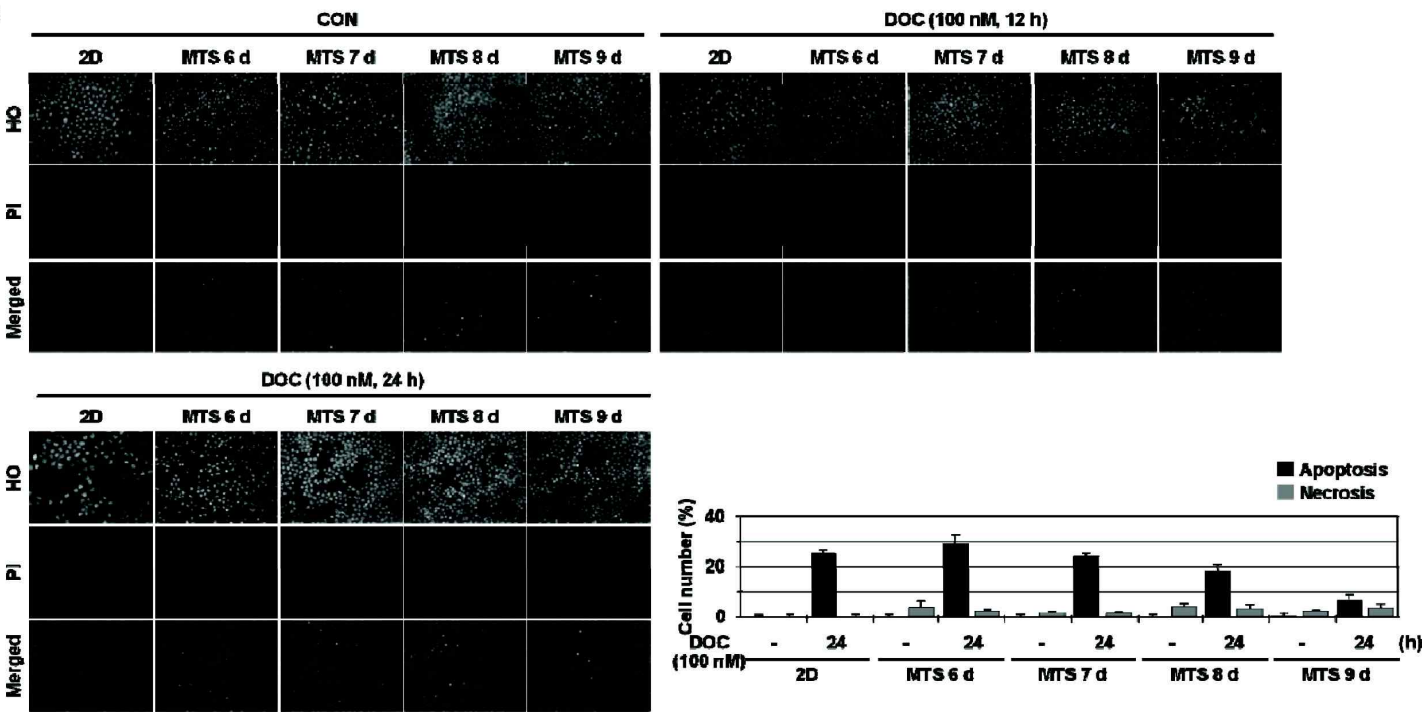

Fig. 3. Switch of cisplatin-induced apoptosis in spheroid cultures of MCF-7 cells. (A) Formation, growth and morphology of MTSs derived from MCF-7 cells. MCF-7 cells were seeded into 1.2\% agarose-coated 96-well plates at a density of 400 cells per well and grown as MTSs. (B) MCF-7 MTSs were cultured for 6 and 8 days and exposed to $50 \mu \mathrm{M}$ cisplatin for $48 \mathrm{hr}$. MTS were dissociated into individual cells as described in 'Materials and methods' and stained with HO/PI staining and observed by fluorescence microscopy. Apoptotic and necrotic cells were scored. Results (500-800 cells in each group) are expressed as the means \pm SE from three independent experiments. ${ }^{*} p<0.05$ versus cisplatin alone treated to $2 \mathrm{D}$-cultured cells. (C) MCF-7 MTSs were cultured for up to 9 days and exposed to $100 \mathrm{nM}$ DOC for the indicated times. MTS were dissociated into individual cells as described in 'Materials and methods' and stained with HO/PI staining and observed by fluorescence microscopy. Apoptotic and necrotic cells were scored. Results (500-800 cells in each group) are expressed as the means \pm SE from three independent experiments. 
gradient with an outer rim of proliferating cells that surrounds an inner shell of G0-phase cells and a necrotic core region [6,11,21]. As demonstrated previously [12], when seeded in non-adhesive conditions, MCF-7 cells formed a compact spherical shape of spheroids (Fig. 3A). When MCF-7 spheroids reached approximately $600-700 \mu \mathrm{m}$ in diameters beginning at 8 days, necrotic cells were detected, indicating that MCF-7 spheroids form the necrotic core after 8 days of culture [12].

Next, we examined the cytotoxic effects of cisplatin and docetaxel using MCF-7 spheroids. To determine the cell death mode, drug-treated MCF-7 spheroids were collected and dissociated into single cells and stained with $\mathrm{HO}$ and PI. As shown in Fig. 3B, $50 \mu \mathrm{M}$ cisplatin-induced apoptosis was markedly reduced in 6 days of spheroids, compared with that of monolayers. We found that cisplatin-induced apoptosis was switched to necrosis in MCF-7 multicellular tumor spheroids that were cultured for 8 days and had necrotic core (Fig. 3B). However, DOC-induced apoptosis was prevented but was not switched to necrosis (Fig. 3C). Previously, we found that DOC-induced apoptosis was gradually reduced during MCF-7 spheroid culture compared to that in monolayers and that prominent resistance to DOC was observed when spheroids containing the necrotic core were treated [12].

\section{Increase in RAGE levels in extended MTS culture}

HMGB1 binds to the receptor for advanced glycation end products (RAGEs) to exert its biological activities. To investigate whether the HMGB1-RAGE signaling pathway is activated in MCF-7 spheroids, cellular proteins obtained from

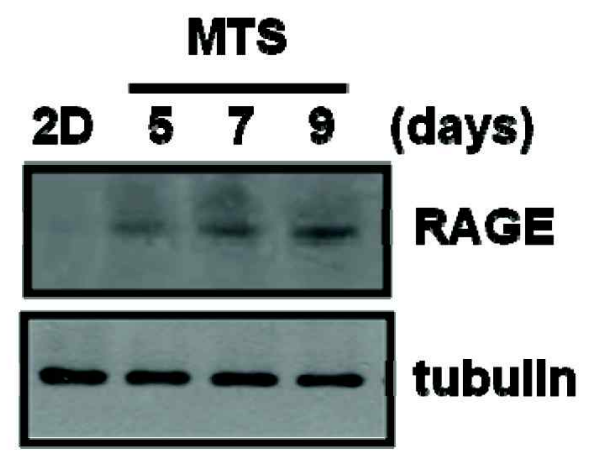

Fig. 4. Increased expression of RAGE in MCF-7 spheroids. MCF-7 MTS was cultured on agarose for the indicated days. Immunoblot analysis was carried out with the cell lysates obtained from MCF-7 2D and 3D culture using anti-RAGE and anti-a-tubulin antibodies.
2-D culture and spheroids were analyzed by Western blotting using antibodies to RAGE. As shown in Fig. 4, the levels of RAGE, a receptor of HMGB1, were increased with extended culture of MTS compared to 2-D culture and spheroids without necrotic core, indicating that RAGE expression is closely linked to the necrotic core formation in MTS.

\section{Discussion}

Anticancer drugs exert chemotherapeutic effects mostly by inducing apoptosis [31]. In this study we showed that rhHMGB1 prevents cisplatin-induced apoptosis and switches the cell death mode to necrosis in MCF-7, MDA-MB231, and MDA-MB361 cell culture and MCF-7 MTS model system (Fig. 2 and 3). Similar apoptosis-to-necrosis switch effect of rhHMGB1 was observed in MDA-MB231 and MDA-MB361 cell culture and MDA-MB361 spheroids treated with 4-HC $(15 \mu \mathrm{g} / \mathrm{ml})$, another alkylating agent (data not shown). The HMGB1 protein is known to trigger autophagy or apoptosis in cancer cells, depending on its redox status $[27,28]$. Although oxidized HMGB1 increases the cytotoxicity of anti-cancer agents and induces apoptosis mediated by the mitochondrial pathway and the caspase- $9 /-3$ intrinsic pathway [28], reducible HMGB1 promotes tumor resistance to alkylators, tubulin disrupting agents, DNA crosslinkers and DNA intercalators by binding to the receptor for RAGEs, but not to Toll-like receptor 4. In addition, RAGE inhibits apoptosis by a p53 transcription-independent pathway during the response to chemotherapeutic agents and sustains autophagy associated with decreased phosphorylation of the mammalian target of rapamycin (mTOR) $[15,16]$. Furthermore, HMGB1 short hairpin RNA transfection or inhibition of HMGB1 release by ethyl pyruvate predominantly induces apoptosis and decreases autophagy in stressed cancer cells [28]. Our results that HMGB1 switches alkylating agent-induced apoptosis to necrosis show an additional activity of HMGB1 in cell death regulation. Cisplatin and 4-HC, DNA alkylating agents, could affect mitochondrial function, whereas DOC is an inhibitor of microtubule remodeling that stabilizes microtubules and prevents tubulin depolymerization. Mitochondrial dysfunction has been linked to the induction of necrosis. For instance, mitochondrial dysfunction is associated with the shift to a glycolytic metabolism, which confers advantages on cancer cells by apoptosis avoidance. In addition, mitochondrial deregulations have been suggested 
to make tumor cells more sensitive to oxidative stress and cell killing induced by GD and 2-deoxyglucose, a glycolysis inhibitor. Furthermore, tumor cells with dysregulated mitochondria undergo necrosis instead of apoptosis in response to alkylating DNA damage that induces rapid ATP depletion through PARP activation [33]. Thus, HMGB1 may impair mitochondrial respiration to make tumor cells more sensitive to anticancer drugs and to die by necrosis instead of apoptosis. Recently, Guerriero et al. [8] showed that using a xenograft mouse tumor system generated from genetically defined cells deficient in apoptosis, cyclophosphamide (CP), a DNA alkylating agent, induces necrosis in tumors evident by tumor cell morphology, extracellular release of HMGB1, and activation of innate immune cells in CP-treated tumors, indicating that in apoptosis-deficient tumors, necrosis may play a fundamental role in tumor clearance by stimulating the innate immune response [8]. Necrosis has been suggested to promote tumor growth $[20,24,30]$. Thus, our results imply that the current alkylating agent-based chemotherapy needs to be reconsidered. The strategy to prevent necrosis as an undesirable action of alkylating agent-based chemotherapy should be delineated to improve the efficacy of chemotherapy for cancer and a deeper understanding of how HMGB1 affects chemotherapy and tumor cell death is needed to design strategically designed alkylating agent-based anticancer treatment.

\section{Acknowledgement}

This work was supported for two years by Pusan National University Research Grant.

\section{References}

1. Castedo, M., J. L. Perfettini, T. Roumier, K. Andreau, R. Medema, and G. Kroemer. 2004. Cell death by mitotic catastrophe: a molecular definition. Oncogene 23, 2825-2837.

2. Desoize, B. and J. Jardillier. 2000. Multicellular resistance: a paradigm for clinical resistance? Crit. Rev. Oncol. Hematol. 36, 193-207.

3. Fagagna d'Adda di, F. 2008. Living on a break: cellular senescence as a DNA-damage response. Nat. Rev. Cancer 8, 512-522.

4. Friedrich, J., C. Seidel, R. Ebner, and L. A. Kunz-Schughart. 2009. Spheroid-based drug screen: considerations and practical approach. Nat. Protoc. 4, 309-324.

5. Golstein, P. and G. Kroemer. 2007. Cell death by necrosis: towards a molecular definition. Trends Biochem Sci. 32, $37-43$.
6. Gottfried, E., L. A. Kunz-Schughart, R. Andreesen, and M. Kreutz. 2006. Brave little world: spheroids as an in vitro model to study tumour-immune-cell interactions. Cell Cycle 5, 691-695.

7. Grivennikov, S. I., F. R. Greten, and M. Karin. 2010. Immunity, inflammation, and cancer. Cell 140, 883-899.

8. Guerriero, J. L., D. Ditsworth, Y. Fan, F. Zhao, H. C. Crawford, and W. X. Zong. 2008. Chemotherapy induces tumor clearance independent of apoptosis. Cancer Res. 68, 9595-9600.

9. Hanahan, D. and R. A. Weinberg. 2011. Hallmarks of cancer: the next generation. Cell 144, 646-674.

10. Horning, J. L., S. K. Sahoo, S. Vijayaraghavalu, S. Dimitrijevic, J. K. Vasir, T. K. Jain, A. K. Panda, and V. Labhasetwar. 2008. 3-D tumour model for in vitro evaluation of anticancer drugs. Mol. Pharm 5, 849-862.

11. Ivascu, A. and M. Kubbies. 2007. Diversity of cell-mediated adhesions in breast cancer spheroids. Int. J. Oncol. 31, 1403-1413.

12. Jeong, E. K., S. Y. Lee, H. M. Jeon, M. K. Ju, C. H. Kim, and H. S. Kang. 2010. Role of extracellular signal-regulated kinase (ERK) $1 / 2$ in multicellular resistance to docetaxel in MCF-7 cells. Int. J. Oncol. 37, 655-661.

13. Jin, S. and E. White. 2007. Role of autophagy in cancer: management of metabolic stress. Autophagy 3, 28-31.

14. Jin, S., R. S. DiPaola, R. Mathew, and E. White. 2007. Metabolic catastrophe as a means to cancer cell death. $J$. Cell Sci. 120, 379-383.

15. Kang, R., D. Tang, M. T. Loze, and H. J. Zeh. 2011. Apoptosis to autophagy switch triggered by the MHC class III-encoded receptor for advanced glycation endproducts (RAGE). Autophagy 7, 91-93.

16. Kemp, C. J., S. Sun, and K. E. Gurley. 2001. p53 induction and apoptosis in response to radio- and chemotherapy in vivo is tumor-type-dependent. Cancer Res. 61, 327-332.

17. Kim, C. H., S. I. Han, S. Y. Lee, H. S. Youk, J. Y. Moon, H. Q. Duong, M. J. Park, Y. M. Joo, H. G. Park, Y. J. Kim, M. A. Yoo, S. C. Lim, and H. S. Kang. 2007. Protein kinase C-ERK1/2 signal pathway switches glucose depletion-induced necrosis to apoptosis by regulating superoxide dismutases and suppressing reactive oxygen species production in A549 lung cancer cells. J. Cell. Physiol. 211, 371-385.

18. Kroemer, G., L. Galluzzi, P. Vandenabeele, J. Abrams, E. S. Alnemri, E. H. Baehrecke, M. V. Blagosklonny, W. S. El-Deiry, P. Golstein, D. R. Green, M. Hengartner, R. A. Knight, S. Kumar, S. A. Lipton, W. Malorni, G. Nuñez, M. E. Peter, J. Tschopp, J. Yuan, M. Piacentini, B. Zhivotovsky, and G. Melino. 2009. Classification of cell death: recommendations of the Nomenclature Committee on Cell Death 2009. Cell Death Differ. 16, 3-11.

19. Liu, P. L., J. R. Tsai, J. J. Hwang, S. H. Chou, Y. J. Cheng, F. Y. Lin, Y. L. Chen, C. Y. Hung, W. C. Chen, Y. H. Chen, and I. W. Chong. 2010. High-mobility group box 1-mediated matrix metalloproteinase-9 expression in non-small cell lung cancer contributes to tumor cell invasiveness. Am J. Respir. 
Cell Mol. Biol. 43, 530-538.

20. Lotze, M. T. and K. J. Tracey. 2005. High-mobility group box 1 protein (HMGB1): nuclear weapon in the immune arsenal. Nat. Rev. Immunol. 5, 331-342.

21. Mueller-Klieser, W. F. and R. M. Sutherland. 1982. Influence of convection in the growth medium on oxygen tensions in multicellular tumour spheroids. Cancer Res. 42, 237-242.

22. Okada, H. and T. W. Mak. 2004. Pathways of apoptotic and non-apoptotic death in tumour cells. Nat. Rev. Cancer 4, 592-603.

23. Roninson, I. B., E. V. Broude, and B. D. Chang. 2001. If not apoptosis, then what? Treatment-induced senescence and mitotic catastrophe in tumor cells. Drug Resist. Updat. 4, 303-313.

24. Scaffidi, P., T. Misteli, and M. E. Bianchi. 2002. Release of chromatin protein HMGB1 by necrotic cells triggers inflammation. Nature 418, 191-195.

25. Schlueter, C., H. Weber, B. Meyer, P. Rogalla, K. Roser, S. Hauke, and J. Bullerdiek. 2005. Angiogenetic signaling through hypoxia: HMGB1: an angiogenetic switch molecule. Am J. Pathol. 166, 1259-1263.

26. Taguchi, A., D. C. Blood, G. del Toro, A. Canet, D. C. Lee, W. Qu, N. Tanji, Y. Lu, E. Lalla, C. Fu, M. A. Hofmann, T. Kislinger, M. Ingram, A. Lu, H. Tanaka, O. Hori, S.
Ogawa, D. M. Stern, and A. M. Schmidt. 2000. Blockade of RAGE-amphoterin signalling suppresses tumour growth and metastases. Nature 405, 354-360.

27. Tang, D., M. T. Loze, H. J. Zeh, and R. Kang. 2010. The redox protein HMGB1 regulates cell death and survival in cancer treatment. Autophagy 6, 1181-1183.

28. Tang, D., R. Kang, C. W. Cheh, K. M. Livesey, X. Liang, N. E. Schapiro, R. Benschop, L. J. Sparvero, A. A. Amoscato, K. J. Tracey, H. J. Zeh, and M. T. Lotze. 2010. HMGB1 release and redox regulates autophagy and apoptosis in cancer cells. Oncogene 29, 5299-5310.

29. Tang, D., R. Kang, H. J. Zeh 3rd, and M. T. Lotze. 2010. High-mobility group box 1 and cancer. Biochim Biophys. Acta. 1799, 131-140.

30. Vakkila, J. and M. T. Lotze. 2004. Inflammation and necrosis promote tumour growth. Nature Rev. Immunol. 4, 641-648.

31. Wilson, T. R., D. B. Longley, and P. G. Johnston. 2006. Chemoresistance in solid tumours. Ann. Oncol. 17, 315-324.

32. Zong, W. X. and C. B. Thompson. 2006. Necrotic death as a cell fate. Genes Dev. 20, 1-15.

33. Zong, W. X., D. Ditsworth, D. E. Bauer, Z. Q. Wang, and C. B. Thompson. 2004. Alkylating DNA damage stimulates a regulated form of necrotic cell death. Genes Dev. 18, 1272-1282.

\section{초록 : HMGB1에 의한 alkylating DNA 손상에 의해 유도된 세포사멸의 세포괴사로의 전환}

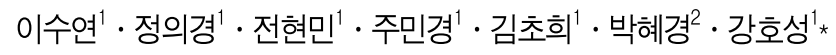

(부산대학교 자연과학대학 분자생물학과, ${ }^{2}$ 한국나노바이오테크놀러지센터)

세포괴사는 세포막의 파열, HMGB1을 포함한 세포 내용물의 세포외부로의 방출 등을 수반하는 세포죽음이다. HMGB1은 핵 단백질로 전사조절자로 작용하지만 세포괴사에 의해 세포 밖으로 방출되면 염증을 유발하고 암을 촉진하는 cytokine으로 작용한다. HMGB1의 과발현은 암 발생 및 항암제 저항과 밀접한 연관성을 가지고 있지 만, 그 기작에 대한 연구는 미흡한 실정이다. 본 연구에서는, HMGB1이 항암제에 의한 세포 죽음에 미치는 영향 을 조사하였다. 그 결과, HMGB1은 MCF-7, MDA-MB231, MDA-MB361 세포에서 cisplatin에 의한 세포사멸을 억제하고 세포운명을 세포괴사로 바꾼다는 사실을 확인하였다. HMGB1의 세포사멸-세포괴사 전환 작용을 4-HC 를 처리한 세포에서도 관찰되었다. 그러나, HMGB1은 docetaxel (DOC)에 의한 세포사멸에는 영향을 주지 않음을 확인하였다. MTS를 이용하여 항암제에 의한 세포 죽음에 미치는 영향을 조사한 결과, necrotic core가 형성된 8일 째 MCF-7 MTS에서 cisplatin에 의한 세포사멸이 세포괴사로 바뀌는 반면, DOC에 의한 세포사멸은 세포괴사로 전환되지 않는 것을 확인하였다. 또한 spheroid에서 HMGB1 receptor인 RAGE의 발현이 증가함을 확인하였다. 이러한 결과를 통해, HMGB1이 alkylating agent에 의한 세포사멸을 세포괴사로 전환시킴을 알 수 있었다. 따라 서, alkylating agent에 의한 항암제 효능을 나타내기 위해선, 이들 항암제의 부작용 즉 세포괴사를 억제하는 전략 이 필요한 것으로 생각된다. 